\title{
Prognostic Significance of the Expression of Claudin-1 in Head and Neck Squamous Cell Carcinoma
}

\author{
Jin Lee ${ }^{1} \mathbb{D}$, Sun Woo Kim ${ }^{1} \mathbb{D}$, Sang Hyuk Lee ${ }^{1} \mathbb{D}$, Sung Min Jin ${ }^{1}$, Sung Im Do $^{2}$, and Hyun Joo Lee ${ }^{2}$ \\ ${ }^{1}$ Departments of Otorhinolaryngology-Head and Neck Surgery, ${ }^{2}$ Pathology, Kangbuk Samsung Hospital, Sungkyunkwan University \\ School of Medicine, Seoul, Korea
}

두경부 편평세포암에서 Claudin-1 발현의 예후인자적 의미

이 진 $^{1} \cdot$ 김선우 $^{1} \cdot$ 이상혁 $^{1} \cdot$ 진성민 $^{1} \cdot$ 도성임 $^{2} \cdot$ 이현주 $^{2}$

성균관대학교 의과대학 강북삼성병원 이비인후과학교실, ${ }^{1}$ 병리학교실

Received April 29, 2020

Revised July 3,2020

Accepted July 21, 2020

Address for correspondence

Sang Hyuk Lee, MD

Departments of Otorhinolaryngology-

Head and Neck Surgery,

Kangbuk Samsung Hospital,

Sungkyunkwan University

School of Medicine,

29 Saemunan-ro, Jongno-gu,

Seoul 03181 , Korea

Tel $+82-2-2001-2264$

Fax $+82-2-2001-2273$

E-mail entlsh@hanmail.net
Background and Objectives Claudin-1 (CLDN-1) is the major component of tight junctions and functions in controlling cell to cell adhesion. Certain claudins were expressed aberrantly and proved to have prognostic significance in various human cancers. However, its clinical significance has been poorly understood in head and neck squamous cell carcinoma (HNSCC). The aim of this study was to investigate the relationship between CLDN-1 expression and clinicopathologic parameters in HNSCC.

Subjects and Method The surgical specimens of primary HNSCCs from a consecutive cohort of 91 patients were retrospectively collected. Immunohistochemical staining for CLDN-1 was performed blindly by two pathologists. CLDN-1 staining intensity was scored semi-quantitatively on a scale of 0 to 3 ( 0 : negative; 1 : weak; 2: moderate; 3 : strong). For the statistical analysis, the expression levels were classified as low (negative and weak) and high (moderate and strong). Next, the association between CLDN-1 expression and clinicopathological features \& clinical outcomes was analyzed.

Results The increased CLDN-1 expression was significantly associated with lymphatic invasion $(p=0.019)$. The expression level of CLDN-1 was not associated with pathological T stage, lymph node metastasis or recurrence. Kaplan-Meier analysis found that 3-year overall survival (OS) rate was $53 \%$ in patients with high level CLDN-1 expression and $74 \%$ in patients with low level CLDN-1 expression. It also found that 5-year OS rate was $49 \%$ in patients with high level CLDN-1 expression and $68 \%$ in patients with low level CLDN-1 expression. A significantly poor OS rate was recorded in patients with high level of CLDN-1 expression compared to patients with low level CLDN-1 expression ( $p=0.022$ ).

Conclusion CLDN-1 may serve as useful prognostic marker in patients with HNSCCs. Korean J Otorhinolaryngol-Head Neck Surg 2021;64(5):336-43

Key Words Claudin-1 · Immunohistochemistry · Prognosis · Squamous cell carcinoma of head and neck · Tight junctions.

\section{서 론}

두경부 편평세포암(head and neck squamous cell carci-

This is an Open Access article distributed under the terms of the Creative Commons Attribution Non-Commercial License (https://creativecommons.org/licenses/by-nc/4.0) which permits unrestricted non-commercial use, distribution, and reproduction in any medium, provided the original work is properly cited. noma, HNSCC)은 전 세계에서 매년 650000건이 새로 진단 되고, 연간 350000건의 사망률을 기록하는 여섯 번째로 흔 한 암이다.1) 두경부암의 분자적 기전은 암의 근본적인 병인 을 잘 이해하고 환자의 예후와 치료 결과를 향상시키기 위해 꾸준히 연구되어왔으나 지속적인 연구에도 불구하고 두경부 암 환자의 사망률은 크게 감소하지 않았다. ${ }^{2)}$ 따라서 앞으로 
는 기존에 잘 알려진 예후 인자에서 더 나아가 새로운 예후 인자들에 대한 연구가 필요한 실정이다. 최근 암의 성장 및 전 이에 대한 연구가 이루어지면서 부착 분자(adhesion molecule) 에 관한 관심이 높아졌고, 여러 연구에서 부착 분자들이 암의 진행에 있어 중요한 역할을 한다고 보고되고 있다.,4)

Claudin은 세포 간 부착 기능을 담당하는 연결복합체 (junctional complex) 중 밀착연접(tight junction)을 이루는 주요한 막단백질(transmembrane protein)이다. 밀착연접은 물, 이온, 단백질 분자와 같은 물질이 세포와 세포 사이 공간 (paracellular pathway)을 통해 이동하는 것을 막는 장벽 (barrier) 역할을 하며, 동시에 세포막을 정단부(apical)와 기 저측부(basolateral) 영역으로 나누어 세포의 극성(cell polarity)을 띄게 한다. ${ }^{5)}$ Claudin은 현재까지 24개의 아형이 밝 혀졌으며, 조직마다 각각 다른 아형이 발현된다. ${ }^{2)}$ 여러 암에 서 claudin의 발현에 대한 연구들이 보고되고 있으며, 조직 및 병변에 따라 발현되는 claudin의 종류와 발현 양상이 달 라 claudin은 조직 특이적 기능을 가질 수 있다. ${ }^{2,6}$

두경부암에서는 claudin-1(CLDN-1)이 claudin의 24개 아 형 중에서 가장 활발하게 연구되고 있으며, 두경부 편평세포 암 안에서는 주로 구강암과 CLDN-1에 대한 연구가 보고되 었다.,7) 그러나 구강암 외 다른 두경부암에서 CLDN-1의 발 현 양상과 임상 병리학적 연관성에 대해서는 아직 충분한 연 구가 이뤄지지 않았다. 이에 본 연구자들은 구강암을 비롯하 여 여러 두경부암 환자를 대상으로 CLDN-1의 발현 양상 및 발현 정도에 따른 임상병리학적 특성을 알아보고자 본 연구 를 진행하였다.

\section{대상 및 방법}

\section{대 상}

2006년 1월 2015년 6월까지 두경부 편평세포암(HNSCC) 을 진단받고 수술적 치료를 시행한 91명을 연속적 코호트 방 식(consecutive cohort study)으로 선정하였다. 병변의 원발 부위는 구강 23예, 구인두 15예, 후두 33예, 하인두 13예, 비 부비동 7예였고, 수술 시 적출된 원발 부위 종양을 대상으로 CLDN-1에 대한 면역조직 화학염색을 시행하였다. 연구 대 상의 병리 진단 보고서를 참고하고 보관된 조직 슬라이드를 재검토하여 조직학적 유형과 침습 깊이, 분화도, 림프절 전이 유무를 조사하였고, 대상 환자의 의무기록과 추적 조사를 통해 나이, 성별 등의 임상양상과 TNM 병기, 임상병기 및 생존 유무를 조사하였다. 91명의 환자에서 경부절제술의 시 행 여부는 수술 전 영상학적 검사 결과와 원발 부위 등 임상 양상을 고려하여 결정하였다. 추적 관찰은 수술 후 첫해에는
$1 \sim 3$ 개월마다, 두 번째와 세 번째 해에 2 4개월마다, 네 번째, 다섯 번째 해에는 3 6개월마다, 그 이후로는 환자의 상태 및 증상에 따라 6개월 1년마다 외래를 방문하도록 하였고, 면 밀한 이학적 검사 및 내시경 검사와 정기적인 영상학적 검사 를 통해 재발 여부를 평가하였다. 전체 생존 기간은 치료 시 작일부터 사망보고일 또는 마지막 추적일까지로 산정하였다. 환자가 사망 시 사망 원인을 분석하여 두경부암으로 사망한 환자들을 대상으로 질병 특이 생존율(disease specific survival)을 구하였고, 두경부암이 사인이 된 경우만을 고려한 생존율로 정의하였다.

\section{방 법}

\section{면역조직화학염색}

포르말린에 고정된 조직을 점진적 고농도의 에탄올로 탈 수시키고 파라핀에 포매시켰다. 파라핀 블록을 표준 회전형 박절기(rotatory microtome)를 사용하여 $4 \mu \mathrm{m}$ 두께로 절단 하고, 수도수로 세정 후 새 슬라이드에 옮겼다. BOND polymer intense detection system(Vision BioSystems, Mount Waverley, Australia)을 제조사의 지침에 따라 사용하여 조 직을 면역조직화학염색 함으로써 CLDN-1 단백의 발현을 평가하였다. 조직 절편을 Bond dewax 용액(Vision BioSystems)으로 탈파라핀화(deparaffinization)하고, $100^{\circ} \mathrm{C}$ 에서 30분 동안 Bond epitope retrieval 용액(Vision BioSystems) 을 사용하여 항원 복구(antigen retrieval)를 수행하였다. 내 인성 과산화효소의 활성을 억제하기 위해 과산화 수소 용액 에 5 분간 처리하였다. 그 후 조직 절편을 CLDN-1에 대한 토 끼의 다클론 항체(polyclonal antibody)(1:150, Abcam, Cambridge, UK)와 함께 15분간 주위 온도(ambient temperature)에서 배양하였다. 비오틴(biotin)이 없는 고추냉이 과산화효소(horseradish peroxicase)-링커(linker) 항체 접 합 시스템을 BondmaX 자동 조직 염색기(Vision BioSystems)와 함께 사용하였다. 발색제로는 $1 \mathrm{mM} \mathrm{3,3-다이아미노}$ 벤지딘(diaminobenzidine), $50 \mathrm{mM}$ Tris- $\mathrm{HCl}$ 완충액( $\mathrm{pH}$ 7.6), 그리고 $0.006 \%$ 과산화수소 용액을 반응시켜 세척하였고, hematoxylin으로 대조 염색을 실시하였다. 표준 절차에 따라 조직 슬라이드를 탈수시키고 커버 슬립으로 밀봉하였다.

\section{면역조직화학염색 결과의 판독}

염색결과의 판독은 2 명의 병리전문의에 의하여 과거의 조 직병리학적, 임상적 정보 없이 시행되었으며 200배, 400 배 광 학현미경 소견하에서 판독하였다. CLDN-1 면역조직화학염 색에서 세포막에 분명한 갈색의 반응을 보일 때 의미 있는 
것으로 판독하였다. CLDN-1의 세포막 염색 강도는 0 3까지 반정량적으로 구분되었다(0: negative; 1 : weak; 2: moderate; 3: strong)(Fig. 1). 2명의 병리 전문의는 개별적으로 전 체 환자 슬라이드에 대한 판독을 위 기준에 맞춰 시행하였 고, 판독된 결과를 비교하여 서로 다른 판독 결과를 보이는 환자의 슬라이드에 대해서는 재판독을 시행하였다. 통계학적 인 비교 분석을 위해 염색 결과의 판정을 두 개의 군으로 나 누어서 0,1 을 약양성 발현군(low), 2, 3을 강양성 발현군 (high)으로 구분하였다.

\section{통계 분석}

CLDN-1의 발현 정도에 따라 환자의 임상병기, 경부 림프 절 전이 여부, 재발과의 상관관계를 chi-square와 Fisher's extract, 그리고 linear by linear association 검정으로 분석 하였고, 유의수준을 $p<0.05$ 를 의미 있는 것으로 하였다. 경 부 림프절 전이와 연관성이 있는 위험 요인을 찾기 위해 logistic regression 분석법을 사용했다. 또한 생존 기간은 $\mathrm{Ka}-$ plan-Meier법을 이용하였고, CLDN-1의 발현 정도에 따른 생존 기간의 차이는 $\log -\mathrm{rank}$ 법을 이용하여 비교 분석하였다.

\section{결 과}

전체 환자는 91명으로 병변의 원발 부위는 구강 23예, 구 인두 15예, 후두 33예, 하인두 13예, 비부비동 7예였다(Table 1). 임상 병기는 8th American Joint Committee on Cancer staging system에 따라 결정하였다.

\section{성별 및 연령과 CLDN-1의 발현 정도}

전체 환자 91명 중 남자 73명(80.2\%), 여자 18명(19.8\%)이 었으며 평균 나이는 65세(31 85세)였다. CLDN-1은 73예의 남자 중 63예(86\%)에서 강한 수준의 발현을 보였고, 나머지 10 예(14\%)에서는 약한 수준의 발현을 나타냈다. 여자에서는 18 예 중 9예(50\%)에서 강한 발현, 나머지 9예(50\%)에서 약한 발현을 보였다. 따라서 남성에서 CLDN-1의 발현이 더 강하 게 나타나는 결과를 보였고, 이는 통계적으로 의미 있는 결과 를 보였다 $(p=0.002)$. 연령별로는 60세 이상인 군이 57예 (62.6\%), 60세 미만인 군이 34예(37.4\%)이었다. 60세 이상인 군에서 CLDN-1의 발현은 57예 중 46예(80.7\%)에서 강한 발 현, 나머지 11예(19.3\%)에서 약한 발현을 보였고 60세 미만인 군에서는 34예 중 26예(76.5\%)에서 강한 발현, 나머지 8예 (23.5\%)에서 약한 발현을 나타냈다. 연령별 두 군과 CLDN-1
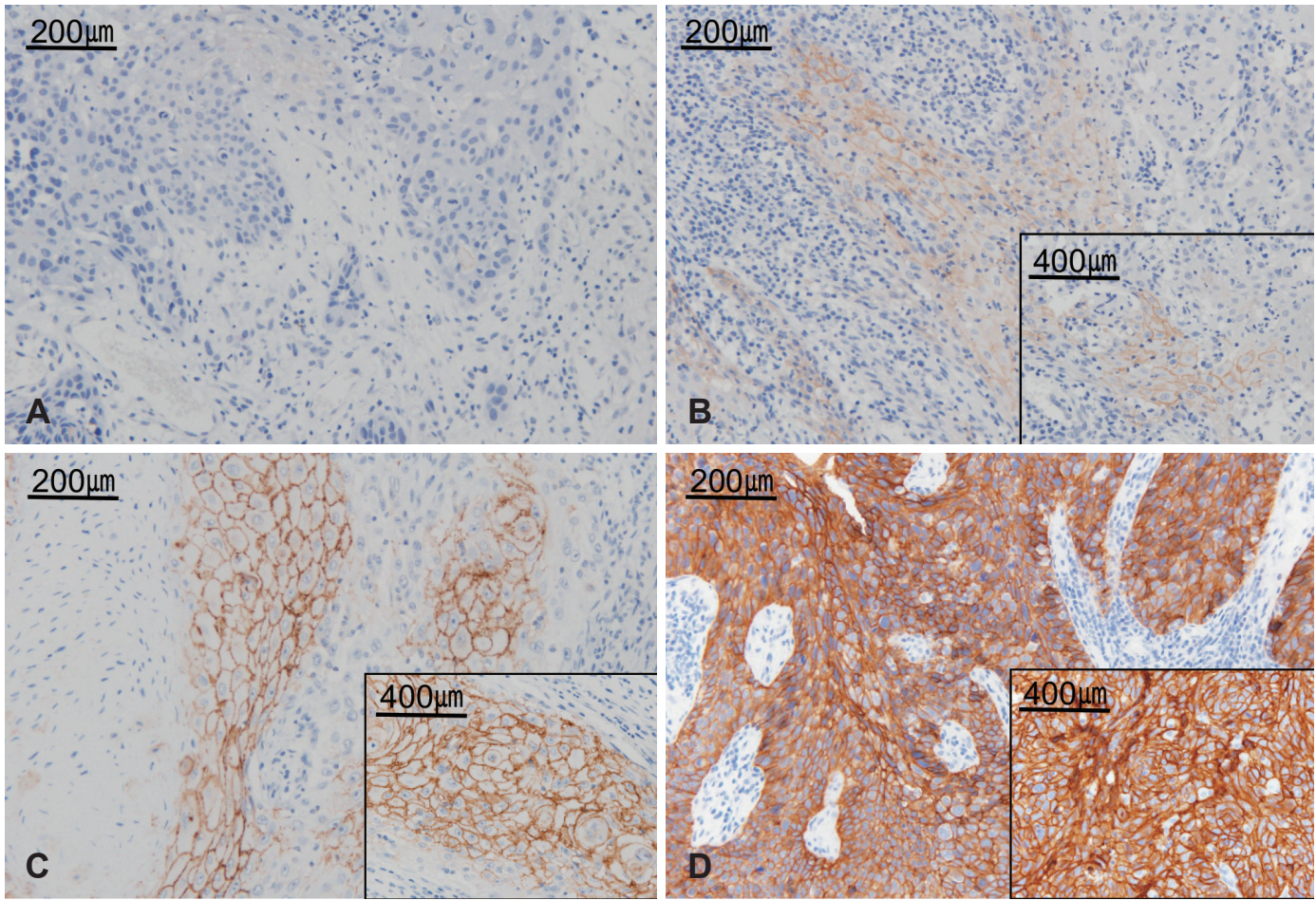

Fig. 1. Representative photomicrographs of immunohistochemical staining for CLDN-1 in HNSCC (magnification $\times 200, \times 400$ ). CLDN-1 staining was read as meaningful when it showed a clear brown reaction to the cell membrane. CLDN-1 staining intensity was scored on a scale of 0 to 3. 0: negative CLDN-1 expression (A), 1: weak CLDN-1 expression (B), 2: moderate CLDN-1 expression (C), 3: strong CLDN-1 expression (D). CLDN-1: claudin-1. 
Table 1. Relationship between CLDN-1 expression and clinicopathological parameters for patients with head and neck squamous cell carcinoma

\begin{tabular}{|c|c|c|c|c|}
\hline \multirow{2}{*}{ Variables } & \multirow{2}{*}{$\begin{array}{l}\text { No. of } \\
\text { cases }\end{array}$} & \multicolumn{2}{|c|}{ CLDN-1 expression } & \multirow{2}{*}{$p$-value } \\
\hline & & Low & High & \\
\hline Sex & & & & 0.002 \\
\hline Male & 73 & 10 & 63 & \\
\hline Female & 18 & 9 & 9 & \\
\hline Age (years) & & & & 0.631 \\
\hline$\geq 60$ & 57 & 11 & 46 & \\
\hline$<60$ & 34 & 8 & 26 & \\
\hline \multicolumn{5}{|l|}{ Primary site } \\
\hline Oral cavity & 23 & 9 & 14 & \\
\hline Oropharynx & 15 & 4 & 11 & \\
\hline Larynx & 33 & 5 & 28 & \\
\hline Hypopharynx & 13 & 1 & 12 & \\
\hline Paranasal sinus & 7 & 0 & 7 & \\
\hline Pathological T stage & & & & 0.542 \\
\hline $\mathrm{Tl}$ & 24 & 4 & 20 & \\
\hline $\mathrm{T} 2$ & 28 & 8 & 20 & \\
\hline T3 & 16 & 4 & 12 & \\
\hline $\mathrm{T} 4$ & 23 & 3 & 20 & \\
\hline N stage & & & & 0.905 \\
\hline NO & 49 & 10 & 39 & \\
\hline $\mathrm{N}+$ & 42 & 9 & 33 & \\
\hline Recurrence & & & & 0.660 \\
\hline $\mathrm{R}(-)$ & 71 & 16 & 55 & \\
\hline $\mathrm{R}(+)$ & 20 & 6 & 14 & \\
\hline \multicolumn{5}{|l|}{ Tumor invasion } \\
\hline Lymphatic invasion & & & & 0.019 \\
\hline$(-)$ & 67 & 18 & 49 & \\
\hline$(+)$ & 24 & 1 & 23 & \\
\hline Vascular invasion & & & & 1.000 \\
\hline$(-)$ & 83 & 18 & 65 & \\
\hline$(+)$ & 8 & 1 & 7 & \\
\hline Perineural invasion & & & & 0.680 \\
\hline$(-)$ & 81 & 18 & 63 & \\
\hline$(+)$ & 10 & 1 & 9 & \\
\hline
\end{tabular}

CLDN-1: claudin-1

의 발현 정도 간에 통계적 유의성은 없었다( $p=0.631)(T a b l e ~ 1)$.

\section{CLDN-1의 면역조직화학적 발현 양상}

전체 두경부암 91예 중 72예(79\%)가 강양성 발현군에 속 하였고, 원발 부위별로 구강 23예 중 14예(61\%), 구인두 15예 중 11예(73\%), 후두 33예 중 28예(85\%), 하인두 13예 중 12예 (92\%), 비부비동 7예 중 7예(100\%)에서 강양성 발현을 보였다 (Table 1). 모든 원발 부위에서 CLDN-1이 강하게 발현되는 경 우가 보다 우세한 것으로 나타났고, 그 중 구강암과 비부비동
Table 2. Analysis of relationship between CLDN-1 expression and lymphatic invasion according to primary site

\begin{tabular}{|c|c|c|c|c|}
\hline \multirow{2}{*}{ Variables } & \multirow{2}{*}{$\begin{array}{l}\text { No. of } \\
\text { cases }\end{array}$} & \multicolumn{2}{|c|}{ CLDN-1 expression } & \multirow{2}{*}{$p$-value } \\
\hline & & Low & High & \\
\hline \multicolumn{5}{|l|}{ Lymphatic invasion } \\
\hline \multicolumn{5}{|l|}{ Primary site } \\
\hline 1) Oral cavity & 2 & 1 & 1 & 1.000 \\
\hline 2) Oropharynx & 5 & 0 & 5 & 0.231 \\
\hline 3) Larynx & 6 & 0 & 6 & 0.556 \\
\hline 4) Hypopharynx & 7 & 0 & 7 & 0.462 \\
\hline 5) Paranasal sinus & 4 & 0 & 4 & $-{ }^{\dagger}$ \\
\hline Total & 24 & 1 & 23 & $0.019^{*}$ \\
\hline
\end{tabular}

*statistically significant, tin paranasal sinus cancer, 7 of 7 cases all showed high level expression of CLDN-1, so analysis of association with low level expression group was not possible. CLDN1: claudin-1

암을 제외한 구인두암, 후두암, 하인두암 세 군에서는 CLDN-1 강양성 군이 61예 중 51예(83\%)로 구강암의 $61 \%$ 보다 비교적 높은 발현율을 보였다.

\section{$\mathrm{CLDN}-1$ 의 발현 정도와 임상병리학적 특성과의 상관관계}

CLDN-1 발현 정도에 따른 종양의 림프관 침윤은 CLDN-1 강양성 발현에서 23예(96\%), 약양성 발현에서 1예(4\%)로 CLDN-1 강양성 발현군에서 통계적으로 유의하게 높은 종 양의 림프관 침윤을 보였다 $(p=0.019)$. 그러나 대상을 원발 부 위별로 나누어 구강암, 구인두암, 후두암, 하인두암 각각에서 CLDN-1 발현 정도에 따른 림프관 침윤에 대해 비교하였을 때는, 네 군 모두 통계학적으로 유의한 차이를 보이지 않았다 (구강암: $p=1.000$, 구인두암: $p=0.231$, 후두암: $p=0.556$, 하인 두암: $p=0.462$ ). 비부비동암에서는 7예 중 7예 모두 강양성 발현을 보였기 때문에 약양성 발현군이 존재하지 않아 둘 사 이의 연관성 분석이 불가하였다(Table 2). 원발 부위 중 구강 암에서는 CLDN-1 발현 정도에 따른 림프관 침윤에 대해 통 계적 유의성을 보이지 않았으나 $(p=1.000)$ 앞서 CLDN- 1 의 높 은 발현율을 보였던 구인두암, 후두암, 하인두암 세 군을 대상 으로 비교하였을 때는 CLDN-1 강양성 발현군에서 통계적 으로 유의하게 높은 종양의 림프관 침윤을 보였다 $(p=0.026)$.

CLDN-1 발현 정도에 따른 임상병리학적 요인들과의 연관 성 분석에서는 전체 두경부암 91예에서 $\mathrm{T}$ 병기, $\mathrm{N}$ 병기, 재발 과 CLDN-1의 발현 정도는 통계학적으로 유의한 상관관계를 보이지 않았다 $(p>0.05$ )(Table 1). 또한 원발 부위 중 구강암 23예와, 구인두암, 후두암, 하인두암 61예를 대상으로 한 분석 에서도 위의 요인들과 CLDN-1의 발현 정도는 통계적으로 유의한 상관관계를 보이지 않았다 $(p>0.05) . \mathrm{CLDN}^{-1}$ 발현 정도 인자와 함께 임상병리학적 요인들 중 경부 림프절 전이 
의 위험요인을 찾기 위한 다변량 분석에서는 $\mathrm{T}$ 병기, 림프관 침윤 여부가 경부 림프절 전이에 중요한 인자였다(T stage: odds ratio=1.899, lymphatic invasion: odds ratio=4.684) (Table 3).

\section{생존율 분석}

본 연구의 HNSCC 환자 91명에서 Kaplan-Meier 방법에 의한 전체 생존율(overall survival)은 3년째에 64\%, 5년째에 $53 \%$ 였다. 질병 특이 생존율(disease specific survival)은 3년 째에 $78 \%, 5$ 년째에 $70 \%$ 였다. CLDN-1 발현 정도에 따라 생 존율에 차이가 있었고 CLDN-1 강양성 발현군의 전체 생존 율이 3년째에 53\%, 5년째에 49\%였고, CLDN-1 약양성 발현 군 전체 생존율 3년째에 $74 \%, 5$ 년째에 $68 \%$ 로 CLDN-1 강양 성 발현군의 전체 생존율이 약양성 발현군보다 유의하게 낮 았다 $(p=0.022)$ (Fig. 2). 원발 부위별 CLDN-1의 발현 정도에 따른 전체 생존율의 차이는 구강암에서만 통계학적 유의성이

Table 3. Multivariate analysis of variables predicting lymph node metastasis

\begin{tabular}{lcccc}
\hline \multicolumn{1}{c}{ Variables } & $\begin{array}{c}\text { Odds } \\
\text { ratio }\end{array}$ & $\begin{array}{c}\text { Lower limit } \\
(95 \% \mathrm{Cl})\end{array}$ & $\begin{array}{c}\text { Upper limit } \\
(95 \% \mathrm{Cl})\end{array}$ & p-value \\
\hline T stage & 1.899 & 1.203 & 2.997 & $0.006^{*}$ \\
Lymphatic invasion & 4.684 & 1.367 & 16.050 & $0.014^{*}$ \\
Vascular invasion & & & & 0.999 \\
Perineural invasion & & & 0.803 \\
Claudin-1 expression & & & 0.283 \\
$\quad$ Primary site & & & $>0.05$ \\
\hline * statistically significant. Cl: confidence interval &
\end{tabular}

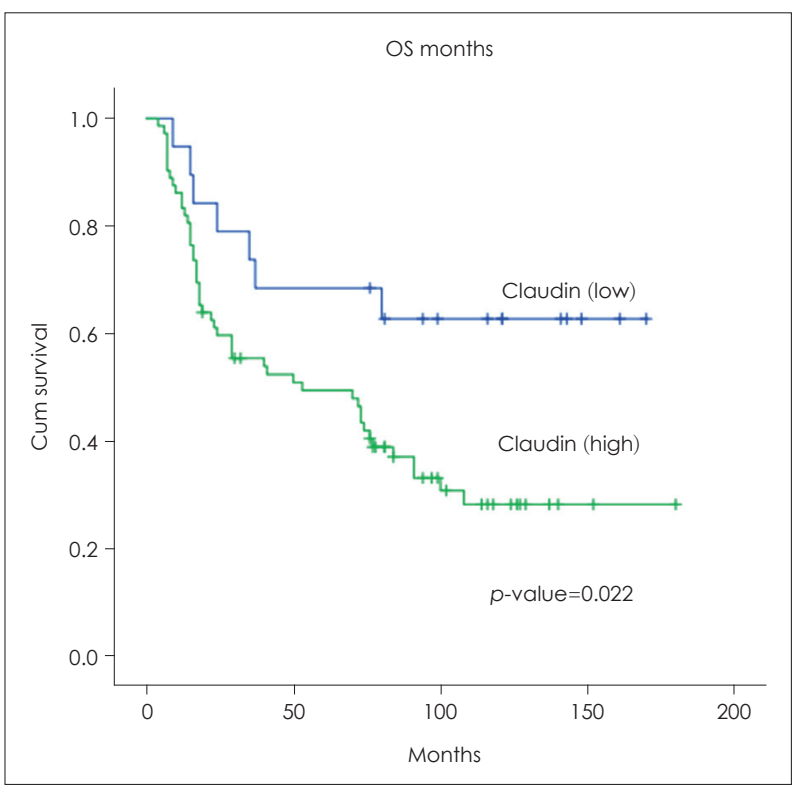

Fig. 2. Kaplan-Meier OS curve of head and neck squamous cell carcinoma patients with low versus high expression of claudin-1 ( $p=$ 0.022). OS: overall survival.
있었으며, 나머지 원발 부위에서는 통계적으로 유의하지 않 았다(구강암: $p=0.004$, 구인두암: $p=0.640$, 후두암: $p=0.589$, 하인두암: $p=0.260)$. 또한 구인두암, 후두암, 하인두암 세 군 을 대상으로 분석하였을 때에도 통계적으로 유의하지 않았 다 $(p=0.941)$. 질병 특이 생존율(disease specific survival)은 3년째에 78\%, 5년째에 70\%였다. CLDN-1 발현 정도에 따라 질병 특이 생존율에 차이가 있었고 CLDN-1 강양성 발현군 의 질병 특이 생존율이 5년째에 $56 \%$ 였고, CLDN-1 약양성 발현군 전체 생존율 5년째에 $89 \%$ 로 CLDN-1 강양성 발현군 의 질병 특이 생존율이 약양성 발현군보다 유의하게 낮았다 $(p=0.044)$

\section{고 찰}

정상 상피조직과 마찬가지로 상피세포 기원 종양의 특징 중 하나는 상피세포가 밀착연접, 부착연접(adherens junction), 데스모좀(desmosome)으로 구성되는 연결복합체를 통 해 주변 세포와 밀착하여 단단히 부착되어 있다는 점이다. ${ }^{8)}$ 연결복합체 중 부착연접과 데스모좀이 주변 세포와의 기계 적인 접착 기능을 담당하는 반면, 밀착연접은 세포층(cell sheet)의 단단한 봉합에 필수적이며, 세포의 극성 유지, 세포 주위에서 일어나는 물질의 수송, 운반 조절 및 장벽 기능에 중 요한 역할을 한다. ${ }^{9}$ 한편, 암의 주변 침습과 전이 과정은 세포 와 세포 간(cell-to-cell), 세포와 세포 외 기질 간의(cell-toextracellular matrix) 유착(adhesion)과 밀접한 관련을 가지 고 있다. ${ }^{10,11)}$ 이 중 종양 세포와 기질 간의 상호 신호 전달은 특히 종양 세포가 특정 장기에 안착하여 성장하는 데 중요하 다. ${ }^{12)}$ 종양세포는 흔히 세포 분화 및 극성의 감소를 보이면서 밀착연접의 기능이 비정상적으로 나타난다. ${ }^{13,14)}$ 밀착연접의 기능 손실은 세포 내로 영양분의 확산을 용이하게 하여 종 양 세포의 성장을 촉진시킨다. 또한 종양 세포의 분화 및 극 성의 감소는 종양 세포가 원발 부위에서 떨어져 나와 림프계 또는 혈류를 타고 이동하여 특정 장기에 전이되는 데 기여한 다. ${ }^{15,16)}$ 이는 연결복합체를 이루는 세포 간 부착 장치가 암세포 들의 활성을 강력하게 조절하고, 질병 진행에 중요한 역할을 할 수 있음을 시사한다. ${ }^{17,18)}$ 또한, 최근 연구들은 이러한 세포 간 부착 장치가 세포 증식 및 분화를 조절하는 데에도 관여할 수 있음을 제시하였다. ${ }^{2)}$

Claudin은 밀착연접의 주요 골격을 형성하는 막단백질로 claudin의 발현 정도의 변화와 구조적 변화는 세포막 표면에서 밀착연접의 구조와 기능에 직접적인 영향을 미친다. ${ }^{19)}$ Claudin 은 다양한 악성 종양에서 비정상적으로 발현되며, 이는 밀착 연접의 정상적인 구조와 기능을 변화시켜 종양 세포의 침습 
성과 전이 가능성을 촉진시킨다. ${ }^{20)}$ Claudin은 현재까지 24개 의 아형이 밝혀졌으며, 정상 세포는 특징적으로 여러 claudin 단백을 발현하지만 어떤 아형의 claudin은 조직 특이적인 분 포를 보인다. 예를 들어, claudin-1은 폐, 간, 신장 모두에서 발현되고, claudin-2는 폐에서는 발현되지 않고 간, 신장에 서는 발현되는 반면, claudin-4는 폐, 신장에서는 발현되고 간에서는 발현되지 않는다. ${ }^{21)}$ 또한 같은 아형의 claudin이더 라도 다양한 암에서 각기 다른 발현 양상을 보인다는 연구 결과가 이미 여러 논문에서 알려져 있다. 예를 들어, CLDN-1 은 대장암, 자궁경부암, 위암, 갑상선암, 요로상피암 등에서 발 현이 증가된 양상을 보였고, ${ }^{22)}$ 유방암, 전립선암, 간세포암에 서는 발현이 감소된 양상을 보였다. ${ }^{12,23,24)}$ 이를 통해서 $\mathrm{clau}^{-}$ din이 조직 특이적 기능을 가질 수 있으며 claudin이 가지는 여러 암에서의 역할이 암세포의 유형 및 암 주변 환경에 따 라 다를 수 있음을 알 수 있다. ${ }^{2)}$ 두경부암에서도 claudin의 발현 양상에 대한 여러 연구가 이루어져왔다. Nelhübel 드이 은 두경부 편평세포암에서의 claudin 아형에 따른 발현 양상 을 분석한 연구를 보고했다. Claudin 24개 아형 중에서 clau$\operatorname{din}-1,2,3,4,7,8,10$ 에 대해 조사하였고, 그 중 claudin-1, 2,7 세 유형이 정상 상피조직과 비교하여 편평세포암종 조직 에서의 발현 양상에서 유의미한 차이를 보였다. 두경부 편평 세포암은 claudin-1과 claudin-7의 발현이 증가한 반면 clau$\operatorname{din}-2$ 의 발현은 유의하게 약한 것으로 나타났다.

본 연구에서는 구강암, 구인두암, 후두암, 하인두암, 부비동 암을 포함하여 여러 두경부암 군에서 CLDN-1의 발현 양상 에 대해 조사하였다. 전체를 대상으로 하였을 때, 그리고 각 각의 원발 부위에 대해서 모두 CLDN-1의 강한 발현이 우세 한 것으로 나타났다. 특히 이미 CLDN-1에 대해 여러 연구가 이루어진 구강암에서보다 구인두암, 후두암, 하인두암 세 군 에서 CLDN-1 강양성 군이 61예 중 51예(83\%)로 비교적 높 은 발현율을 보였다. 종양의 임상병리학적 특징 중에서는 CLDN-1 강양성 발현군에서 림프관 침윤이 더 빈번한 것으 로 나타났으며, 통계적으로 유의했다. 또한 각각의 원발 부위 별 분석에서는 통계적 유의성을 얻지 못하였으나, 구인두, 후 두, 하인두 세 군을 대상으로 한 분석에서는 CLDN-1 발현 정도에 따른 림프관 침윤 여부가 통계적으로 유의한 차이를 보였다. 이에 대해서는 향후 각 원발 부위에 대해, 그리고 특 히 인후두부위에 대해 더 많은 표본을 대상으로 하는 연구 가 필요할 것으로 사료된다. 또한 본 연구에서는 남성에서 CLDN-1의 발현 정도가 더 강한 것으로 나타났으나, 비슷한 다른 연구 결과에서는 성별에 따른 CLDN-1 발현 정도에 통 계적 유의성은 보고되지 않았다.,2,6,7) 91 명의 환자에서 수술 전 영상학적 검사 결과와 원발 부위 등 임상양상을 고려하여
경부절제술 여부를 결정하였고, 그 결과 42 명의 $\mathrm{N}(+)$ 는 선택 적 또는 치료적 경부절제술 시행 후 조직검사로 림프절 전이가 확인된 환자이며, 49 명의 $\mathrm{N}(-)$ 는 선택적 경부절제술 시행 후 조직검사에서 림프절 전이가 관찰되지 않은 환자 22명과 영상 진단에서 경부 전이가 의심되지 않으며 잠재 전이 가능성이 낮아 경부절제술을 시행하지 않은 27명으로 구성되어 있다. 경부절제술을 시행하지 않은 27명의 환자는 주로 경부 전이 가 드문 후두암이나 그 외 $\mathrm{T}$ 병기가 낮은 조기의 구강암 환자 들이었고, 추적 관찰에서 경부 전이가 발견된 경우는 없었다.

본 연구의 한계점으로는 첫째, 후향적으로 진행된 연구라 는 점, 두 번째로는 원발 부위별 표본 수가 고르지 못한 점이 며, 세 번째로는 종양 조직과 동일한 환자에서의 정상 조직과 의 비교가 이루어지지 못한 점이다. 본 연구는 두경부 편평세 포암에서 CLDN-1의 강한 발현이 종양의 림프관 침윤성을 증가시키며 낮은 생존율과 유의한 관련을 보인다는 결과를 얻었다. 그러나 원발 부위별로 구강암만을 대상으로 했을 땐 이전 구강암에서 CLDN-1 발현과 관련하여 보고된 몇몇 연 구와는 다른 결과를 보였다. Dos Reis 등ㄱㅇㅢ 연구에서는 구 강암에서 발현이 증가된 $\mathrm{CLDN}-1$ 이 공격적인 암의 특성에 서 보이는 혈관림프관 침습과 신경주위 침습과 연관성이 있 다고 보고하였다. 또한 Sappayatosok과 Phattarataratip ${ }^{2}$ 의 연구에서는 구강암에서 CLDN-1의 증가된 발현이 임상 병 기와 암의 병리학적 특성 중 신경주위 침습, 혈관 침습, 림프 절 전이와 연관된다고 밝혔다. 본 연구에서는 전체 두경부암 에서는 CLDN-1 강양성 발현군에서 림프관 침윤이 증가한 다는 결과를 얻었으나 구강암 23예만을 대상으로 했을 때엔 통계적 유의성을 얻지 못했다. 이러한 결과의 차이는 본 연구의 구강암에서 종양의 침습이 관찰된 표본 수가 위 연구에서 보 고된 건수에 비해 적은 것에서 기인했을 것이라 사료된다. 본 연구에서는 구강암 23예 중 림프관 침윤이 2예(8.7\%)에서만 관 찰되며, 혈관 침윤은 1 예(4.3\%), 신경주위 침습은 4예(17.4)가 관찰되었고, Sappayatosok과 Phattarataratip ${ }^{2)}$ 의 연구에서는 구강암 환자 45예를 대상으로 혈관 침습 19예(42.2), 신경주 위 침습 17예(37.8\%)가 관찰되었다. Claudin은 밀착연접의 기 능을 유지하는 데 중요한 역할을 하고 있으며, 두경부 편평세 포암에서 비정상적으로 발현이 증가된 CLDN-1이 밀착연접 의 정상적인 구조와 기능을 변화시킴으로써 종양의 림프관 침윤, 종양의 침습성을 증가시키는 데 영향을 줄 것으로 보여 진다. ${ }^{20)}$ 일부 고형 종양에서는 종양의 림프관 침윤이 예후에 미치는 중요성이 잘 알려져 있는 것에 반해, ${ }^{25-27)}$ 두경부 편평 세포암에서는 많은 연구가 보고되었으나 아직까지는 이에 대 한 충분한 합의가 이루어지지 않았다. ${ }^{28-30)}$ Jones 드ㅇㅣㅣ은 구강 암에서 림프관 침윤이 생존율에 영향을 미친다고 보고하였 
고, 또한 림프관 침윤과 경부 림프절 전이와의 연관성에 대해 서도 보고하였다. 이러한 연구 결과는 다른 비슷한 연구들에 서 찾아볼 수 있었으나 ${ }^{32,33)}$ 모든 연구에서 림프관 침윤과 경 부 림프절 전이와의 연관성을 일관되게 입증하지는 못했다. 향후 두경부암의 분자적 기전과 CLDN-1에 대한 추가적인 연구를 통해 CLDN-1은 두경부암에서 유용한 예후 인자로 쓰일 수 있을 것이며, 더 나아가 분자적 치료 영역에서 표적 치료에도 이용될 수 있을 것으로 기대된다.

\section{Acknowledgments}

This study was supported by a National Research Foundation of Korea (NRF) grant funded by the Korean government (NRF-2020 R1F1A1071489 to SH Lee).

\section{Author Contribution}

Conceptualization: Sang Hyuk Lee, Sung Im Do. Data curation: Jin Lee, Sung Im Do, Hyun Joo Lee. Investigation: Sun Woo Kim, Sung Min Jin. Methodology: Jin Lee, Sung Im Do, Hyun Joo Lee. Project administration: Jin Lee. Software: Jin Lee. Supervision: Sang Hyuk Lee, Sung Im Do, Hyun Joo Lee. Validation: Jin Lee, Sung Min Jin. Visualization: Jin Lee, Sun Woo Kim. Writing-original draft: Jin Lee. Writing — review \& editing: Sang Hyuk Lee, Jin Lee.

\section{ORCIDs}

Sang Hyuk Lee

https://orcid.org/0000-0003-4412-3486

Jin Lee https://orcid.org/0000-0003-2264-8310

Sun Woo Kim

https://orcid.org/0000-0002-2894-1334

\section{REFERENCES}

1) Nelhúbel GA, Károly B, Szabó B, Lotz G, Kiss A, Tóvári J, et al. The prognostic role of claudins in head and neck squamous cell carcinomas. Pathol Oncol Res 2014;20(1):99-106.

2) Sappayatosok K, Phattarataratip E. Overexpression of claudin-1 is associated with advanced clinical stage and invasive pathologic characteristics of oral squamous cell carcinoma. Head Neck Pathol 2015;9(2):173-80.

3) Sobel G, Páska C, Szabó I, Kiss A, Kádár A, Schaff Z. Increased expression of claudins in cervical squamous intraepithelial neoplasia and invasive carcinoma. Hum Pathol 2005;36(2):162-9.

4) Kondoh A, Takano K, Kojima T, Ohkuni T, Kamekura R, Ogasawara $\mathrm{N}$, et al. Altered expression of claudin-1, claudin-7, and tricellulin regardless of human papilloma virus infection in human tonsillar squamous cell carcinoma. Acta Otolaryngol 2011;131(8):861-8.

5) Escudero-Esparza A, Jiang WG, Martin TA. The claudin family and its role in cancer and metastasis. Front Biosci (Landmark Ed) 2011;16:1069-83.

6) Lourenço SV, Coutinho-Camillo CM, Buim ME, Pereira CM, Carvalho AL, Kowalski LP, et al. Oral squamous cell carcinoma: Status of tight junction claudins in the different histopathological patterns and relationship with clinical parameters. A tissue-microarraybased study of 136 cases. J Clin Pathol 2010;63(7):609-14.

7) Dos Reis PP, Bharadwaj RR, Machado J, Macmillan C, Pintilie M, Sukhai MA, et al. Claudin 1 overexpression increases invasion and is associated with aggressive histological features in oral squamous cell carcinoma. Cancer 2008;113(11):3169-80.

8) Schneeberger EE, Lynch RD. The tight junction: A multifunctional complex. Am J Physiol Cell Physiol 2004;286(6):C1213-28.

9) Tsukita S, Furuse M, Itoh M. Multifunctional strands in tight junctions. Nat Rev Mol Cell Biol 2001;2(4):285-93.

10) Mina LA, Sledge GW Jr. Rethinking the metastatic cascade as a therapeutic target. Nat Rev Clin Oncol 2011;8(6):325-32.

11) Li WJ, Zhang ZL, Yu XM, Cai XL, Pan XL, Yang XY. Expression of claudin-1 and its relationship with lymphatic microvessel generation in hypopharyngeal squamous cell carcinoma. Genet Mol Res 2015; 14(4):11814-26.

12) Tabariès $\mathrm{S}$, Siegel PM. The role of claudins in cancer metastasis. Oncogene 2017;36(9):1176-90.

13) Weinstein RS, Merk FB, Alroy J. The structure and function of intercellular junctions in cancer. Adv Cancer Res 1976;23:23-89.

14) Soler AP, Miller RD, Laughlin KV, Carp NZ, Klurfeld DM, Mullin JM. Increased tight junctional permeability is associated with the development of colon cancer. Carcinogenesis 1999;20(8):1425-31.

15) Martin TA, Jiang WG. Tight junctions and their role in cancer metastasis. Histol Histopathol 2001;16(4):1183-95.

16) Wodarz A. Tumor suppressors: Linking cell polarity and growth control. Curr Biol 2000;10(17):R624-6.

17) Oku N, Sasabe E, Ueta E, Yamamoto T, Osaki T. Tight junction protein claudin-1 enhances the invasive activity of oral squamous cell carcinoma cells by promoting cleavage of laminin- 5 gamma2 chain via matrix metalloproteinase (MMP)-2 and membrane-type MMP-1. Cancer Res 2006;66(10):5251-7.

18) Morin PJ. Claudin proteins in human cancer: Promising new targets for diagnosis and therapy. Cancer Res 2005;65(21):9603-6.

19) Heiskala M, Peterson PA, Yang Y. The roles of claudin superfamily proteins in paracellular transport. Traffic 2001;2(2):92-8.

20) Harhaj NS, Antonetti DA. Regulation of tight junctions and loss of barrier function in pathophysiology. Int J Biochem Cell Biol 2004; 36(7):1206-37.

21) Mitic LL, Van Itallie CM, Anderson JM. Molecular physiology and pathophysiology of tight junctions I. Tight junction structure and function: Lessons from mutant animals and proteins. Am J Physiol Gastrointest Liver Physiol 2000;279(2):G250-4.

22) Ding L, Lu Z, Lu Q, Chen YH. The claudin family of proteins in human malignancy: A clinical perspective. Cancer Manag Res 2013; 5:367-75.

23) Morohashi S, Kusumi T, Sato F, Odagiri H, Chiba H, Yoshihara S, et al. Decreased expression of claudin-1 correlates with recurrence status in breast cancer. Int J Mol Med 2007;20(2):139-43.

24) Myal Y, Leygue E, Blanchard AA. Claudin 1 in breast tumorigenesis: Revelation of a possible novel "claudin high" subset of breast cancers. J Biomed Biotechnol 2010;2010:956897.

25) Algaba F. Lymphovascular invasion as a prognostic tool for advanced bladder cancer. Curr Opin Urol 2006;16(5):367-71.

26) Kim JM, Kim TY, Kim WB, Gong G, Kim SC, Hong SJ, et al. Lymphovascular invasion is associated with lateral cervical lymph node metastasis in papillary thyroid carcinoma. Laryngoscope 2006; 116(11):2081-5.

27) Woo CS, Silberman H, Nakamura SK, Ye W, Sposto R, Colburn W, et al. Lymph node status combined with lymphovascular invasion creates a more powerful tool for predicting outcome in patients with invasive breast cancer. Am J Surg 2002;184(4):337-40.

28) Fives C, Feeley L, O'Leary G, Sheahan P. Importance of lymphovascular invasion and invasive front on survival in floor of mouth cancer. Head Neck 2016;38 Suppl 1:E1528-34.

29) Adel M, Kao HK, Hsu CL, Huang JJ, Lee LY, Huang Y, et al. Evaluation of lymphatic and vascular invasion in relation to clinicopathological factors and treatment outcome in oral cavity squamous cell carcinoma. Medicine (Baltimore) 2015;94(43):e1510.

30) Jardim JF, Francisco AL, Gondak R, Damascena A, Kowalski LP. Prognostic impact of perineural invasion and lymphovascular invasion in advanced stage oral squamous cell carcinoma. Int J Oral Maxillofac Surg 2015;44(1):23-8 
31) Jones HB, Sykes A, Bayman N, Sloan P, Swindell R, Patel M, et al. The impact of lymphovascular invasion on survival in oral carcinoma. Oral Oncol 2009;45(1):10-5.

32) Close LG, Burns DK, Reisch J, Schaefer SD. Microvascular invasion in cancer of the oral cavity and oropharynx. Arch Otolaryngol Head Neck Surg 1987;113(11):1191-5.
33) Klijanienko J, el-Naggar AK, de Braud F, Rodriguez-Peralto JL, Rodriguez R, Itzhaki M, et al. Tumor vascularization, mitotic index, histopathologic grade, and DNA ploidy in the assessment of 114 head and neck squamous cell carcinomas. Cancer 1995;75(7):164956. 